\title{
The Development of the Concept of Contributory Negligence in Civil and Common Law. A Comparison*
}

\author{
EMANUEL G.D. VAN DONGEN** \\ HENRIËTTE P. VERDAM***
}

\begin{abstract}
The injured party's own conduct contributing to the damage suffered has been a bar to the recovery of damages in delictual liability for centuries, both in the traditions of civil as well as common law. This article describes and compares the historical development, from (classical) Roman law up to French, German and Dutch law in the beginning of the $20^{\text {th }}$ century, of the method with which cases involving the behaviour of the injured party contributed to the occurrence of damage - nowadays called 'contributory negligence', with the English common law tradition from the medieval period until the Law Reform (Contributory Negligence) Act of 1945. In both the civil and the common law traditions, the result of 'contributory negligence' was the same - all or nothing. Solutions found in civil and common law to deal with the contributory conduct of the injured party are not very different. There might have been remarkable similarities in the way one solved this issue before a concept of contributory negligence existed. Furthermore, whilst the official introduction of the partition of damages as a result of contributory negligence came later in common law than in civil law, early signs of the adoption of this principle can be also be found in 19th century common law.
\end{abstract}

Keywords: contributory negligence; tort law; damages; causation; common law; comparative law

\section{INTRODUCTION}

The two legal families of (Romanic) civil law and (English) common law have had a great impact on contemporary law in Western Europe. Although these traditions have different origins, it does not mean that later developments are fundamentally different. Due to the different basis (and characteristics) of the two traditions, it may not be expected that, when it comes to concrete legal problems, there might be more similarities in the developments of legal concepts in both systems than one might initially think. This article looks at the differences and similarities between the tradition of civil law and (English) common law in the law of delict/tort law by analysing how questions of 'contributory negligence', i.e. cases in which the behaviour of the injured party contributed to the occurrence of damages, were historically solved. The key question will be whether cases in which the behaviour of the injured party contributed to the occurrence of damage were solved in the same way in civil and common law. The contribution of the injured party's own conduct to the damage suffered has been a bar to the recovery of damages for centuries, in the tradition of civil as

* This contribution is an elaborate version of the presentation by the first author at the 4th Comparative Law Workshop which had the theme Comparative Law and the Historical Perspective on 16 October 2015, in Örebro (Sweden).

** Dr. E.G.D. van Dongen is Assistant Professor at the Molengraaff Institute for Private Law, Utrecht University, the Netherlands, and a Research Fellow at the Utrecht Centre for Accountability and Liability Law (UCALL). E-mail: E.G.D.vanDongen@uu.nl

*** H.P. Verdam, LLM is an attorney at Kennedy Van der Laan in Amsterdam, the Netherlands. E-mail: Henriette.Verdam@kvdl.com 
well as in common law. ${ }^{1}$ The legal concept of contributory (or comparative) negligence as known today was however unknown in both traditions in the medieval and early modern periods. This article considers the developments from that period up the beginning of the $20^{\text {th }}$ century, when the concept of contributory negligence had been firmly established in both traditions. For the civil law tradition, the description of the development will start with the (classical) origin of the Roman law, texts that that, in Justinian form, provided the basis for the later development in the period of medieval ius commune.

Under common law, the concept of contributory negligence is no defence for a breach of contract and thus only applies to tort law. ${ }^{2}$ It is a defence in contract law and leads to a reduction of the amount of damages to be paid in civil law jurisdictions e.g., France and Germany. ${ }^{3}$ Hungarian law holds the same position, see $\S 6: 144$ (1) jo. 6:5252 of the Hungarian Civil Code of 2013. In this article, contributory conduct will be shown, in both traditions, to be linked to the (broader) question of causation. The development in the civil law tradition will be dealt with in chronological order in Section 2; Roman law in Antiquity (Section 2.1); the medieval period (Section 2.2); the early modern period (Section 2.3) and the period upto the beginning of the twentieth century (Section 2.4). Following the development of the way in which cases concerning contributory conduct were solved in the common law tradition will be dealt with in Section 3, in two parts. The first part gives an overview of the main theories within the common law tradition, in which contributory negligence, if legally relevant, could only lead to a denial of a claim for damages. This part, too, is presented chronologically, discussing first the medieval and early modern period (Section 3.2) and then the $19^{\text {th }}$ and $20^{\text {th }}$ century (Section 3.3). The second part will single out cases that, in one way or another, indicate some rebellion against, or mitigation of, the leading case law and thus paved the way for a partition of damages (Section 3.4). Finally, in conclusion, it will be shown that, with regard to the substantive law of contributory negligence, the often-stated assumption that common and civil law are very different is (partly) erroneous, as there are some remarkable similarities in the way this issue was solved even before the concept of contributory negligence formally existed (Section 4).

\section{THE CIVIL LAW TRADITION ${ }^{4}$}

\subsection{The casuistic practical approach of the Roman jurists}

In Roman law, the relevant provisions on cases where the injured party contributed to their own loss can be found in the lex Aquilia (probably dating from 286 or $287 \mathrm{BC}$ ), ${ }^{5}$ which concerned the delict damnum iniuria datum (unlawful inflicted damage). Based on the first chapter of the lex Aquilia, a fine had to be paid in the event of the unlawful killing of another's slave or four-footed beast of the class of cattle. ${ }^{6}$ In the third chapter, a fine had to

1 See, on the development in civil law, elaborately Van Dongen (2014a).

2 See e.g. Law Commission (1993) 4; Beale (2015) 26-77.

3 Law Commission (1993) 8; Zimmermann (2014) 212-3.

4 This summary of the development of contributory negligence in the civil law tradition is based on Van Dongen (2014a).

5 See e.g. Kaser (1971) 161; Watson (1984) 234.

${ }^{6}$ Gai. D.2.2pr. 
be paid in the event of burning, shattering, or breaking of another's slave, four-footed beast of the class of cattle or other tangible property. ${ }^{7}$

Analysis of the primary sources has shown that in (post-)classical Roman law, a specific legal notion of contributory negligence, as known today, did not exist. ${ }^{8}$ The examples of the Digest show that technical (dogmatic) theories are often absent from the replies of classical jurists to private citizens (responsa) in cases that, from a functional perspective, can be considered as 'contributory negligence' cases. Furthermore, theories of causation applied to e.g. D.9.2.9.4, containing the rule that the causal nexus between the act of the wrongdoer and the damage might be broken by an act of the injured party, do not satisfactory solve the problem. Such defence is not accepted in cases where the wrongdoer does act wilfully, even though the result ought to be the same regardless of the intentional or merely negligent nature of the act. ${ }^{9}$ The Roman jurists did not apply a theory of culpae compensatio to cases ${ }^{10}$ - medieval and modern scholars forced this theory on the Roman sources. ${ }^{11}$ The Roman jurists merely enquired whether the injury, considering the circumstances, was due to the negligence (culpa) of the wrongdoer. Certain Digest texts, such as the text of the javelin thrower (D.9.2.9.4), show that Roman jurists approached the culpa requirement in a casuistic manner. ${ }^{12}$ Often the matter was approached using the status theory of Hermagoras of Temnos ( $2^{\text {nd }}$ cent. BC), which allowed a more precise argument on the legal problem at stake. ${ }^{13}$ This is a method to determine what is at issue in a case that results from rhetorical arguments. The term status refers to the nature of the quaestio resulting from the confrontation between a claim and a defence. ${ }^{14}$ This theory had a central place in the search for arguments used by jurists to substantiate their decision persuasively. ${ }^{15}$

The only and final question in classical Roman law was whether the wrongdoer had been at fault (culpa) or not due to the penal character of the actio legis Aquiliae (the actio based on the lex Aquilia) and to the wording of the lex Aquilia. In the formulary procedure, the iudex's only possibility was to condemn the defendant to pay the poena if convinced that the requirements of the formula were fulfilled, otherwise he had to absolve the defendant. The possibility to reduce the poena - due to the negligence of the injured party did not exist. ${ }^{16}$ In that respect, in classical Roman law, it was not possible to balance of the culpable behaviour of the two parties, but only to asses of the culpable behaviour of the wrongdoer. Consequently, looking at the preponderant negligence is also nonsensical for classical Roman law. ${ }^{17}$

7 Ulp. D.9.2.27.5.

8 Van Dongen (2014a) 13-104.

9 Buckland, McNair \& Lawson (1974) 372; Buckland \& Stein (2007) 587; Van Dongen (2014a) 65 .

${ }_{10}$ Differently see Pernice (1867) 60-2; Von Lübtow (1971) 106, 136.

11 Van Dongen (2014a) 94, 103 and also already Valditara (1994) 862.

12 See also Zimmermann (1996) 1008.

13 This was for example the case in Alfenus D.9.2.52.1. See on this text also Van Dongen (2010) 163-76.

14 Leesen (2009) 35.

15 Van Dongen (2014a) 50-1.

16 See also Wollschläger (1976) 135.

17 An elaborate discussion of this theory as well as of its origin can be found in Van Dongen (2014a). 
This important characteristic, the all-or-nothing approach, was retained in Justinian law (sixth cent.) and enforced until the lex Aquilia lost its penal character, only in early modern times. In Justinian law, the fragments concerning the lex Aquilia, written by various Roman jurists, could be read in relation to each other, as they were now promulgated by Emperor Justinian (482-565) as being part of one and the same title. Furthermore, they could be read in relation to other texts of Justinian's compilation, such as D.50.17.203 (Quod quis ex culpa sua damnum sentit, non intellegitur damnum sentire), a rule which was regarded as a general principle from that time on. This became a general rule by being placed into the title De diversis regulis iuris antiqui - the original (classical) context was something totally different, namely the law of legacies. ${ }^{18}$ Because of the formulation as a regula, it was generally set up as an abstract principle, both valid for delictual and contractual remedies. ${ }^{19}$ Therefore, it was not possible to claim recovery in Justinian law if the victim caused his injury by his own fault. There could be no consequences of contributory negligence other than a denial of claims based on the insufficiency in the requirements of the actio legis Aquiliae. It is inconceivable that a restriction of the obligation to pay full compensation, in the sense that the wrongdoer was only liable for part of the damage was recognised in Justinian law. ${ }^{20}$

There are just some scattered texts in the Digest in which the behaviour of the injured party results in the restriction of the amount of damage to be paid by the wrongdoer, namely to be found in contract law (D.19.1.11.12 and D.19.1.45.1). ${ }^{21}$ There are no traces of a general rule based on a generalisation of these texts in post-classical times. Furthermore, there is no dogmatical foundation for the view that a restriction of liability of the wrongdoer existed and can be found in D.50.17.203, nor did this text refer to mutual blame of both parties. $^{22}$

\subsection{Legal discussions on the contributory act of the injured party in the Medieval period}

According to the glossators, the injured party (owner of the slave/object) could petition for an actio legis Aquiliae when someone inflicted damage to someone else's property. The requirements for a successful action were that the act causing the damage was unlawful (iniuria); that the damage had to be inflicted as a result of the negligence (culpa) of the wrongdoer $-i$.e. not acting with due care ${ }^{23}$ and that there was a causal connection. ${ }^{24}$

The question of how to qualify the act of the injured party in legal terms was first explicitly discussed in medieval times, when a discussion of the acts of both parties concerned could be observed for the first time. In medieval Roman legal scholarship, the contributory negligence of the injured party seems to have been regarded as reproachable

18 Lenel (1889) pal. nr. 6.260; see on the original (classical) context Van Dongen (2014a) $16-30$.

19 Aumann (1964) 31; Van Dongen (2014a) 30.

20 Van Dongen (2014a) 100.

21 Luig (1969) 193; see Medicus (1962) 322-3; Aumann (1964) 14 et seq.

22 Van Dongen (2014a) 101-2.

${ }^{23}$ I.e. what can be foreseen by a diligent person (D.9.2.31); later Bartolus, in his commentary on D.16.3.32., argued that liability consists in any deviation from the diligence of a careful person. See also Hallebeek (2001) esp. 76-7; Descamps (2005) 76-7.

24 See also Descamps (2005) 27. 
misconduct to be sanctioned by a refusal of any claim for damages. ${ }^{25}$ Two starting points for the problem of contributory negligence can be identified in this period. The first starting point is the doctrine of culpae compensatio; the second starting point is identified in the rule laid down in D.50.17.203. ${ }^{26}$ The first starting point was the doctrine of culpae compensatio, meaning, according to the glossators, that the contributory negligence of the injured party (culpa) excluded the fault and therefore all liability of the wrongdoer. According to Johannes Bassianus ( $† 1197)$, this would lead to the following result when applied to the case of the javelin thrower (D.9.2.9.4). ${ }^{27}$ The fault (culpa) of the wrongdoer (the javelin thrower) is compensated by the negligent act (culpa) of the injured party and is therefore neutralised. For that reason the javelin thrower was relived from his own culpa. ${ }^{28}$

A comparison of the amount of negligence and a refinement in the sense that a small degree of contributory negligence would not lead to compensatio and thus to the deprivation of the possibility to claim compensation for damages/fine, was probably made by the successors to the glossators at the instigation of the canonists. Some medieval Roman legal scholars used this doctrine of culpae compensatio to solve problems of contributory negligence in cases of damnum iniuria datum, especially Paulus de Castro (ca. 1360/621441). As to the second starting point, Accursius (ca. 1182-1263) linked D.50.17.203 to the law of delicts, namely by the allegation of D.9.2.31. ${ }^{29}$ According to Accursius, an injured party's own negligence prevented him from claiming damages from someone else. D.50.17.203 can be understood in the sense that it only concerns negligence by the injured party. Works of other glossators and the works of the commentators show that the legal rule of D.50.17.203 was interpreted as only concerning cases in which only the injured party was at fault, not cases of contributory negligence. However, Accursius understood it as not only concerning cases in which the negligence of the wrongdoer was not at all under discussion, but also in cases in which that was indeed the case, i.e. cases of contributory negligence.

In medieval canon law, as in medieval Roman law, a wrongdoer was only liable when he was at fault (culpa). ${ }^{30}$ The notion of culpa in canon law was slightly different from that in medieval Roman law. Culpa could exist either when acting in contravention of legal provisions or when doing something permissible but without using the required diligence. ${ }^{31}$ Although the canonists based their assessment of liability on the two elements of damage (damnum) and fault (culpa) without mentioning the causal relation between the damage and the act that caused the damage as a separate requirement, this way of assessment indirectly forced them to consider the problem of causation. ${ }^{32}$ According to canon law, the contributory negligence of the injured party can be seen as contributory causation (co-causation) and therefore in such cases it had to be established whether the wrongdoer or the injured party

25 Also the medieval jurists understood the obligation to pay compensation for damages as a penal sanction; see Jansen (2007) 530-1, 660.

${ }^{26}$ In this sense see also Luig (1969) 198.

27 See e.g. gloss quia non debuit with siglum Io. ad D.9.2.9.4 in Ms. Paris BN, lat. 4459, fo. 90va., written by Johannes Bassianus, adopted by Accursius in gloss quia non debuit ad D.9.2.9.4.

28 See e.g. gloss quia non debuit with siglum Io. ad D.9.2.9.4 in Ms. Paris BN, lat. 4459, fo. 90va., written by Johannes Bassianus, adopted by Accursius in gloss quia non debuit ad D.9.2.9.4.

29 See Accursian gloss Quod quis ad D.50.17.203.

30 X.5.36.9.

31 Kuttner (1935) 201, 225-6; Gordley (2006) 190-1, 196.

32 Von Mehren \& Gordley (1977); Parisi (1992) 106-7; Van Dongen (2014a) 150. 
produced the proximate cause (causa proxima). ${ }^{33}$ It seems that the causational contributions of both parties were compared but causation and fault seem not to have been separated in this period.

The canonists also embraced the theory of culpae compensatio in various areas of law, generally in those areas not dealing with the law of delicts or in cases of the law of delicts in which both persons were laymen. ${ }^{34}$ However, this was different with regard to the question of whether a cleric could be granted a higher ordination, according to the commentary of Animal on D.50 c.50, because in that case culpa could never be compensated by culpa. The author of the Animal also stated that when the wrongdoer and the person killed had both acted culpably, even if the culpability of the first was less serious, the cleric could never be promoted to a higher rank. ${ }^{35}$ Based on some later canon law cases, which did not concern delictual claims based on unlawfully caused damage, it could be argued, as some modern scholars do, that the liability of the tortfeasor in question is cancelled out because of the preponderant contributory negligence (culpa maior) of the injured party. ${ }^{36}$ The majority of the commentaries of the decretalists do not follow such a culpa maior theory. Furthermore, one should be careful with reaching the conclusion that, due to the lack of a possibility to distribute the damages over both parties in case of contributory negligence (which was not at all at stake in the cases of X.5.12.8 and X.5.12.9), the jurists tended to attribute the 'sole guilt' to the party that acted with the highest degree of negligence (analogous interpretation). Only when the negligence of the injured party was more serious than that of the wrongdoer would the liability of the latter fall out of the picture. In later developments the canonists usually solved contributory negligence issues by using the rule in D.50.17.203, which was somewhat modified in the compilation of Bonifacius VIII (r. 1294-1304), i.e. the Liber Sextus (1298). It concerns the rule that one has to impute the damage that someone suffers due to one's own negligence to himself, not to others. ${ }^{37}$ Furthermore, towards the end of the medieval period, mainly in consilia literature, the term culpa admixta (literally 'mixed fault') was used to qualify the behaviour of the injured party in a way that led to the exclusion of the liability of the wrongdoer. In this way contributory negligence led to a denial of a claim without a discussion of the degree of the negligence of each party. ${ }^{38}$

A similar all-or-nothing approach was followed in the event of 'contributory negligence' already in some other medieval sources outside the Roman-canonical tradition (iura propria - indigenous laws). A division of damages was not made in either Roman law or in medieval ius commune. However, this idea of a division of damages can be found in some cases $^{39}$ in other old traditions, e.g. medieval Irish law. ${ }^{40}$ Contributory negligence of

33 Luig (1969) 201; Van Dongen (2014a) 152.

34 See X.5.16.6, the decision of Pope Gregory IX in VI.1.21.1, Dynus de Mugello ad VI.5.12.65 and by Hostiensis in his Summa on the title De damno dato.

35 Animal est substantia (2016) at link 1, ad D.50 c.50

36 Only two remarks by the influential Bernardus Parmensis ( $† 1266)$, see gloss Romanis Pontificis ad X.5.12.8, and Hostiensis (Henricus de Segusio, ca. 1200-1271), see his Commentaria ad X.5.12.9, nr. 2, can provide an indication of the fact that this theory was applied. See Van Dongen (2014a) 146 et seq.

37 See also Lange (1955) 72-3; Luig (1969) 203.

38 See e.g. Cravetta (1611) cons. 119, nr. 11.

39 Van Dongen (2014a) 182-3.

40 See Bretha Étgid $\S 30$. 
the injured party could lead to partial compensation, the judicium rusticorum, or to a reduction of damages to the amount of two-thirds. This judicium rusticorum is interesting as it appeared again in later periods of legal history, such as in Roman-Dutch law.

\subsection{Various techniques to solve 'contributory negligence' in the early modern period}

The Aquilian concepts have sometimes been said to have framed legal thinking on extracontractual liability since the reception of Roman law. ${ }^{41}$ However, the question is what exactly has been received of the lex Aquilia. By the end of the $17^{\text {th }}$ century, it had become manifest that modern law in action no longer reflected the Aquilian delict of the Corpus iuris civilis. ${ }^{42}$ A general action for damage done unlawfully was provided; an action that was only Roman in its name. Around 1700, the general action for damages lost its penal character throughout Europe. ${ }^{43}$ In other respects the lex Aquilia was still considered the basis for delictual liability. The concept of culpa remained essentially the same; wrongfulness remained an essential prerequisite for Aquilian liability. A general theory of causation was never developed or applied. ${ }^{44}$ The adagium Nam qui occasionem damni praestat, damnum fecisse videtur (derived from D.9.2.30.3) was maintained as a criterion for causality in legal doctrine; the question whether the wrongdoer gave the occasion for the damage was often linked up with the broader problem of fault. ${ }^{45}$

An injured party still had no right to claim damages if his negligence contributed to the occurrence of the damage; an all-or-nothing approach still applied. Some humanists envisaged the possibility of partial compensation - the first time in the continental Roman law tradition. ${ }^{46}$ Regarding the substantive law, the humanists were sometimes more strongly rooted in the tradition of mos italicus than might be expected. In writings, there is, amongst others, the application of the culpae compensatio but also the first traces of the maior culpa approach. ${ }^{47}$ In general, in this early modern period, the idea that an equal or preponderant contributory negligence (maior culpa) excluded the right to claim compensation began to gain acceptance. However, not all jurists followed this theory and this was not the only method used to deal with the problem of 'contributory negligence'. Other theories were also applied and other techniques were used to solve the problem. ${ }^{48}$

The issue of contributory negligence is solved in an alternative way in one of these solutions which was applied in Germany and Italy. In the event of injuries suffered in a quarrel, the person who provoked the fight was regarded as the auctor rixae. The auctor rixae could not claim damages for his injuries unless the other person had exceeded the limits of normal selfdefence. In Italy, the Rota Romana sometimes held the view that contributory negligence, no matter how small, had to lead to the dismissal of a claim for compensation, while in other cases the Rota required culpa maior on the side of the injured party. $^{49}$

41 See e.g. Jansen (2004) 450.

42 Coing (1985) 509-10; Zimmermann (1990) 68; 1996 (1018).

43 Dondorp (1998) 64-5, 70.

44 Van Dongen (2014a) 225.

45 Kaufmann (1958) 65; Zimmermann (1990) 78.

46 See Faber (1618) ad D.50.17.203; De Sande (1681) ad D.50.17.203.

47 See chapter 4 of Van Dongen (2014a).

48 Chapter 4 of Van Dongen (2014a)

49 See Van Dongen (2014a) 281 et seq. 
A different starting point compared to Roman law was taken in Roman-Dutch law in ship-collision cases. If two ships collided and both had acted negligently, there were two main views on what the law dictated: (1) If the negligence was equal on both sides, the damage had to be regarded as common and both parties had to bear the damage in equal proportions (the view of the Supreme Court of Holland, Zeeland and West-Friesland); ${ }^{50}$ (2) Each party should bear its own loss, because whoever had been negligent could not bring an action and the damage that occurred was not regarded as damage cf. D.50.17.203. ${ }^{51}$

Another problem was to determine what the law dictated in case a stationary ship was hit by a moving ship. Dionysius G. van der Keessel (1738-1816) considered the negligence of the latter as more serious, and therefore no culpae compensatio (marking the application of the ius commune theory) could take place. Thus one ship had to bear 50 per cent of the damage of the other ship, and so something quite similar to the idea of a division of damage occurred. ${ }^{52}$ This was like the old tradition of judicium rusticorum but with one new aspect, that in case of culpa maior 50 per cent of the damage of the other party had to be paid.

Some natural law jurists did apply the rule of D.50.17.203 in cases of contributory negligence, and in doing so, denied the claim for compensation. Others applied the criterion of culpa maior and only denied the claim for compensation if the contributory negligence of the injured party was more serious than the negligence of the wrongdoer. ${ }^{53}$ The possible attribution of damage both to the wrongdoer and to the injured party (according to the respective faults or causal contributions) had its origin in the 'Aufklärungstheorie' of Christian Wolff (1679-1754) $)^{54}$ and is therefore a relatively recent phenomenon. The assessment and balancing of the respective gradations of the negligence of both parties was already a step in that direction. So, although Wolff was the first legal scholar who turned away from the 'all-or-nothing principle', his theory can also be considered a continuation of the preceding development. Wolff did not treat the matter of contributory negligence in an abstract way, but only for some concrete cases. In particular, no remarks are found as to the relation with the delictual obligation to pay damages. ${ }^{55}$

\subsection{The concept of contributory negligence in the nineteenth century ${ }^{56}$}

Wolff's doctrine seems to have been codified for the first time in $\S 1304$ of the Austrian Allgemeine Bürgerliche Gesetzbuch (1811), the same article in which judicial discretion is provided as to the consequences of contributory negligence. ${ }^{57}$ In French law, the Code civil of 1804 did not contain a general rule on contributory negligence. The topic was dealt with

50 See Neostadius (1667) decisio nr. 49.

51 Cf. D.50.17.203; see Van Bijnkershoek (1744) IV.22, and Van der Keessel (1860) thesis 816.

52 Van Dongen (2014a) 254-5. On the topic of contributory negligence in collision cases see also Van Dongen (2013) 601-10.

53 See Van Dongen (2014a) 285 et seq.

54 Wolff (1750) § 283. See, on the new approach of Chr. Wolff, Van Dongen (2014a) 295-8.

55 In this respect, an older case contained in the Selectae decisiones of Wolffgang A. Schoepff is a much clearer example of a partial compensation of damages in the event of liability for unlawful caused damage, in the sense that some specific sorts of damage (namely the costs of maintenance) could not be recoverable because of the contributory negligence of the injured party. See Schoepff (1726) dec. 192, nr. 5.

56 On the 19th century development see also Van Dongen (2014b).

57 The influence of Wolff on the ABGB was effected by means of Karl A.F. von Martini (17261800) and Franz on Zeiller (1751-1828). See Luig (1969) 232; Jansen (2007) 676. 
in case law and in particular by the Cour de cassation. The partition, made on the basis of the gravity of faults, was accepted by the majority of legal scholars and judges who initially denied the full claim in case of contributory negligence. ${ }^{58}$ This changed at the end of the nineteenth century, when the situation in which the injured party and the wrongdoer were at fault (characterised as faute commune) ${ }^{59}$ led to a partition of damages proportionate to the gravity of the faults on each side. ${ }^{60}$

The situation in nineteenth-century Germany was different. Although the Historical School defended the view that no compensation had to be provided if the injured party had committed (any) contributory negligence, some applied the maior culpa doctrine. The pandectists tried to find new dogmatic reasons to justify the denial of a claim in the event of contributory negligence. Their theories were mainly causation theories, based on the thought of an interruption of the causal connection in the case of contributory negligence. A theory (often) connected to this was the culpae compensatio theory, based on the rule of D.50.17.203. Later, equity was regarded as the foundation of the rule of D.50.17.203. ${ }^{61}$ Regarding the all-or-nothing approach, it was generally stated that individual consequential losses for which the injured party was responsible could not be imputed to the wrongdoer. This was in fact a first attempt to escape the all-or-nothing approach (and the tradition of ius commune). In legal practice, a small degree of contributory negligence already led to a denial of a claim. However, to avoid unfair solutions, this approach was increasingly opposed in legal practice. A reduction of the amount of damages in the event of contributory negligence was accepted for the first time by the German Reichsgericht in $1883 .{ }^{62}$ Somewhat earlier, the natural law solution in Switzerland (particularly in Article 51 II of the Schweizerische Obligationenrecht 1881) had been codified under the influence of ( $\$ 1304$ of) the Austrian Allgemeine Bürgerliche Gesetzbuch (1811) as well as the French doctrine. Eventually, the Swiss code, regarding the problem of contributory negligence, was taken as an example by the drafters of the German Bürgerliche Gesetzbuch (1900) and, also under the influence of case law, the Swiss regulation was adopted in its entirety in $\S 254$. In the application of the concept of Mitverschulden - whose legal doctrinal basis is much debated - leads to an apportionment based on the circumstances of the case, with an emphasis on the preponderant causation. Although the primary standard is causation, the secondary standard is a review of the other circumstances (among which negligence). ${ }^{63}$

In the Netherlands, the Civil Code (Burgerlijk Wetboek) of 1838 did not contain a general provision on contributory negligence. Up to 1916 lower case law rarely applied a

58 For the older cases in which compensation was denied because of contributory negligence, see C Lyon 17 January 1844, S. 1844.2.401 and C Douai 14 December 1846, JdP 1848, 492; see also, e.g., Mazeaud \& Mazeaud (1970) 625; Honoré (1983) 95.

59 The term in itself is inaccurate, since in the situation under study the two parties, wrongdoer and injured party, have nothing in common: neither the damage, nor the fault. Therefore, it is more correct to refer to this as a concurrence of faults - although the contributory fault of the injured party is of different nature than the fault of the wrongdoer. See also Le Tourneau (2004) 444.

60 See Van Dongen (2014a) 315-6.

61 Van Dongen (2014a) 319-21.

62 Reichsgericht 15 October 1883, RGZ 10, 74, 80-1; Aumann (1964) 172.

63 Although § 254 aimed at the predominant causation (vorwiegende Verursachung), the Reichsgericht continued to apply the doctrine of the main fault and this means that the predominant causation seems to have been already interpreted from the start of the twentieth century as überwiegendes Verschulden. See Van Dongen (2014a) 315-6. 
partition of damages in cases of contributory negligence. In the event of contributory negligence the claim was usually denied, (implicitly) based on the rule contained in D.50.17.203 or based on the culpae compensatio doctrine. The legal basis of the denial of damages to the injured party in the event that their act had contributed to their own damage was disputed, although the majority view became that equity demanded the denial of a claim and that the damage should be imputed to the victim if they could have prevented the accident from occurring. ${ }^{64}$ In cases where the culpae compensatio doctrine was applied one often balanced the degree of negligence of the wrongdoer with the contributory negligence of the injured party; the right for compensation was only denied when the contributory negligence of the injured party was more serious than the negligence of the wrongdoer (culpa maior). The all-or-nothing approach ended with the judgement of the Dutch Supreme Court in civil and criminal cases (Hoge Raad) in 1916, in which the court decided that the duty to compensate had to be measured, based on the extent to which the negligence of both parties contributed to the damage. ${ }^{65}$

\section{THE COMMON LAW TRADITION 66}

\subsection{Medieval and early modern common law}

\subsubsection{Introduction}

Roman law was not received in English common law to the same degree received upon the continent but Roman law has definitely had some influence on the concepts, terminology and principles of English common law. ${ }^{67}$ Some thoughts on the topic of contributory negligence have also been taken from Roman law. ${ }^{68}$ It is interesting that the 13 th century English jurist Henry de Bracton (c. 1210-1268), an ecclesiastic and royal judge, referred to Roman law, namely D.9.2.11pr., in his exposé on homicide through misadventure and accidents. ${ }^{69}$ Apparently in cases of (criminally sued) crimes, the behavior of the injured party was irrelevant. ${ }^{70}$ However, the concept of contributory negligence cannot be found as such in the medieval common law of delicts. Furthermore, a general principle of contributory negligence in this period was implausible, due to the various narrow forms of action. ${ }^{71}$ Nevertheless, there were some cases which, when considered from a modern contemporary perspective, dealt with the problem of 'contributory negligence'; these will be discussed in the following sections.

64 Van Dongen (2014a) 325-6.

65 Hoge Raad 4 February 1916, NJ 1916, p. 450. See on this case, elaborately, Van Dongen (2014b).

${ }^{66}$ The part on English law has already been published, but more elaborately, and in a slightly different form, as Van Dongen \& Verdam (2016) 61-74.

${ }^{67}$ See elaborately Re (1961) 447 et seq.

68 Wharton (1874) 265, even claimed that the principle of Pomponius in D.50.17.203 - stating that he who suffers loss due to his own negligence is not considered to have suffered loss - was reaffirmed in Anglo-American jurisprudence.

69 Bracton, De legibus, 384 [ed. with an English translation by Thorne (1968)].

70 The discourse on homicide by Bernard of Pavia was transplanted and by that the scheme of responsibility: in a case of accidental homicide, a man was only acquitted if his act was lawful and if he had used due care. See Pollock \& Maitland (1923) 477.

71 The remaining part of this article will focus on the tort of negligence. 


\subsubsection{Interruption of the causal connection between an act and damage}

The courts in the medieval and early modern period gave form to almost all contemporary institutions of limitation of liability by means of causal imputation. This also applied to 'contributory negligence'. Rather than using a concept of contributory negligence, it was examined whether the harm was caused by the plaintiff's own act, i.e. whether the plaintiff themself were responsible for the proximate cause. That the proximity of causation was the prerequisite for the liability of the defendant becomes clear from the Cattle case, also referred to as Godfrey v. Godfrey (1470). In this case the plaintiff, the injured party, sued the defendant for trespass because the defendant's animals had strayed from the road into the adjoining close, which belonged to the plaintiff. The Court denied the plaintiff's claim because it came to the conclusion that the damage was caused by not properly securing the close and thus by the plaintiff's own conduct. ${ }^{72}$ According to this reasoning the plaintiff's claim was either accepted or denied in full, no halfway solution was possible - i.e. an allor-nothing approach. ${ }^{73}$ No contributory negligence was at stake in this case, because the notion of negligence had not yet arisen. Liability for trespass was strict, rather than faultbased, so all issues, such as 'contributory negligence', had to be based on causation. ${ }^{74}$ The wrongdoer's responsibility only extended to the direct consequences of his act; the (negligent) conduct of the injured party could be used to question the direct connection between the damage and the behaviour of the wrongdoer. The injured party could not therefore claim damages if their act had been the effective cause (the direct, proximate cause) of the damage. ${ }^{75}$ This way of thinking was clearly influenced by the canon law distinction between causa proxima and causa remota (see par. 2.2) ${ }^{76}$ [In some 17th and 18th century cases in which the conduct of the injured party contributed to his loss, the causal connection between the act and the damage was also of major importance.77 For example, in] Brock v. Copeland (1794), Lord Kenyon (1732-1802) decided in a case where the plaintiff had, without any caution, entered a yard with a dog after it had been shut and was bitten by the dog, that the owner of the dog was not at fault. If the dog was kept on the premises of the defendant and the injury was due to the imprudence of the plaintiff entering those premises, the action could not be maintained. ${ }^{78}$

\subsubsection{Appearance of negligence}

Negligence only became a basis for liability in the late 18th century and thus it was only from that period onwards that a denial of a claim based on contributory negligence became possible. ${ }^{79}$ There are nevertheless some cases that point to an early acceptance of the relevance of (contributory) negligence for liability or at least indicate a reformulation of the

72 Godfrey v. Godfrey (1470) Y.B. 10 Ed. IV Pasch pl. 19. See also, e.g., Holdsworth (1966a) 378 et seq.

${ }^{73}$ Koppe (1970) 33 et seq.

74 Ibbetson (1999) 58 et seq.

75 See, e.g., Holdsworth (1966a) 378 and Holdsworth (1966b) 449.

76 See Van Dongen (2014a) 150 et seq. Furthermore, according to the Luig (1969) 225, 237, the proximate cause rule corresponds, as a result, to the prevailing theory of culpa maior in the period of usus modernus.

77 See also Van Dongen \& Verdam (2016) 63.

78 Brock v. Copeland (1794) 170 E.R. 329.

79 See also Turk (1950) 195. 
old doctrine in terms of negligence. These occur in the 16th and 17th centuries, when the concept of negligence, as a ground for liability, worked its way into common law. ${ }^{80} \mathrm{In}$ some of these cases the courts solved contributory negligence by considering the element of negligence, i.e. by denying the claim because the injured party himself had been negligent. ${ }^{81}$ Two examples will be given. In the first case, Bayley v. Merrel (1615), the defendant had hired the plaintiff to carry a load of madder (a herb which was commonly used as a dye) from Exhall to Uppingham and fraudulently deceived him regarding the weight of the goods. Seven of the plaintiff's horses died because the goods were too heavy. The Court denied the horse owner's claim despite the apparent fraud as it considered that the accident was due to the owner's - gross - negligence for making a horse carry a weight which far exceeded the declared weight without noticing or checking the true weight. ${ }^{82}$ In the second case, Cruden v. Fentham (1799), a defendant drove on the wrong side of the road while the plaintiff was on horseback. Although the road was wide enough for both to pass without difficulty, the plaintiff crossed over to the side where the carriage was being driven. The horse was killed in endeavoring to pass between the carriage and the pavement. ${ }^{83}$ Lord Kenyon informed the jury that the plaintiff had thus voluntarily put himself in the way of danger. This argumentation, although not followed by the jury, ${ }^{84}$ was clearly based on negligence rather than causation.

\subsection{9th and 20th century England}

\subsubsection{Butterfield v. Forrester: the idea of 'ordinary caution'}

The concept of negligence as an independent ground for liability took shape in the 18th and early 19th century. ${ }^{85}$ The defence of contributory negligence originated in Butterfield $v$. Forrester (1809) - the leading case on contributory negligence in the early 19th century, although the case itself did not mention the term contributory negligence. ${ }^{86}$ The case concerned a man riding a horse who drove into a pole erected on a public road and was thrown of his horse and injured. The man was denied his claim for damages because he was found to have ridden at extreme speed, not taking ordinary care. According to the judge before whom this case was brought at first instance, an injured party could not recover his loss if he could have avoided the accident or injury by exercising 'ordinary caution'. A subsequent move for an appeal was rejected by Lord Chief Justice Ellenborough (17501818), who declared, without any supporting authority:

'A party is not to cast himself upon an obstruction which has been made by the fault of another, and avail himself of it, if he do not himself use common and ordinary caution to be in the right. In cases of persons riding upon what is considered to be the wrong side of the road that would not authorize another purposely to ride up against them. One person in fault will not dispense with another's using ordinary care for himself. Two things must concur to

80 Heuston \& Buckley (1996) 485.

81 See also Koppe (1970) 33 et seq., and also Van Dongen \& Verdam (2016) 63-4.

82 Bayley v. Merrel (1615) 79 E.R. 331.

83 Cruden v. Fentham (1799) 170 E.R. 496.

${ }^{84}$ Cruden v. Fentham (1799) 170 E.R. 496.

85 Harper \& James (1956) 1195.

86 Butterfield v. Forrester (1809) 11 East 60/103 E.R. 926 (K.B. 1809). 
support this action, an obstruction in the road by the fault of the defendant, and no want of ordinary care to avoid it on part of the plaintiff. ${ }^{87}$

Although there was no doubt that the defendant's careless conduct was a significant cause of the damage, he was not held liable because the court ascribed the accident to the carelessness of the injured party who had ridden violently through the unlit streets and had not detected the obstacle in time. Therefore the accident had occurred entirely as a result of the plaintiff's own fault. ${ }^{88}$ The rationale of the decision is that the contributory negligence of the injured party is a complete defence against an action in negligence for any claim for damages. This leads to the extreme rule that even the slightest amount of contributory negligence bars the injured party's action, even though the wrongdoer's negligence might have been far more severe. ${ }^{89}$ Remarkably, this rule was readily accepted as a well-settled rule - without any arguments made against it and this prejudiced the law for the following 140 years. ${ }^{90}$ If damage was caused by both parties, neither of them could recover anything from the other; 'The loss lies where it falls'. ${ }^{91}$

Doctrinal justifications for the denial of claims for damages in case of contributory conduct by the injured party are mainly found in the theory of causality. In the event of contributory negligence, the act of the injured party, rather than that of the wrongdoer, is regarded as the proximate cause. ${ }^{92}$ Historically, the development of the doctrine of contributory negligence can be understood in light of the context at the time. Several factors might have played a role in the ready acceptance of the rule in Butterfield v. Forrester. While the doctrine has been explained from the perspective of policy and has been attributed a certain penal function, ${ }^{93}$ it has also been explained as a demonstration of the individuality of early capitalism and been attributed to the rise of the Industrial Revolution and the expansion of the economy ${ }^{94}$ or the historical inertia of common law. ${ }^{95}$ Its development might have been encouraged by the uneasy distrust of the plaintiff-minded jury in the earlier part of the 19th century; the desire to keep the liabilities of growing industries within boundaries, as well as the tendency of the courts to look for the proximate cause of every injury and the inability of the courts to conceive a satisfactory method for the partition of damages in the case of a single injury. ${ }^{96}$

87 Butterfield v. Forrester (1809) 11 East 60/103 E.R. 926 (K.B. 1809).

88 See also Koppe (1970) 28 et seq.

89 Swisher (2011) 359.

90 Bohlen (1907-8) 233; Koppe (1970) 28.

91 Williams (1945) 106.

92 Landon (1951) 356; Koppe (1970) 30. Other possible justifications provided are based on the voluntary assumption of risk or the idea that the injured party should come to court with 'clean hands' or are derived from the construction of the injured party and the wrongdoer as joint tortfeasors. See Keeton et al. (1984) 452; Schofield (1889-90) 267 et seq.; Koppe (1970) 30. Elaborately on the dogmatic justifications of the doctrine of contributory negligence see Wester (1976) 21 et seq.

93 Schofield (1889-90) 270, 271. See also Landon (1951) 354.

94 Suggested as a reason in the US by Swisher (2011) 362, but also applicable in the UK. See also Turk (1950) 198. Furthermore, according to Bohlen, the most important reason to adhere to the strict form of contributory negligence until the contemporary period was the spirit of the age of liberalism it came to meet. See Bohlen (1906-7) 17 et seq., note 2, who argues that the form of contributory negligence is possibly the strongest expression that the individualism has found in the law.

95 Koppe (1970) 31.

96 These factors are taken from Keeton et al. (1984) 452 et seq. 


\subsubsection{Award of damages despite negligence}

The rule in Butterfield v. Forrester that an injured party could not recover if there was any negligence on his part was followed in other early 19th century cases. A very strict interpretation of the rule can be found in Hawkins $v$. Cooper, in which a horse and cart knocked down a woman while she was crossing the road. The cart was driving on the wrong side of the road in order to overtake an omnibus, and the horse was found not having a proper bit. The judge of the Court of Common Pleas instructed the jury that they could only find for the woman if the accident was attributable to the driver's fault and 'to that, and that alone'. ${ }^{97}$ If, on the other hand, the accident was occasioned in any degree by improper conduct by the woman herself, the jury had to deny an action for damages. ${ }^{98}$ A parallel can be drawn with the civil law, where this denial of a claim for damages in cases of contributory negligence was also still applied in the early 19 th century. ${ }^{99}$

Although the consequences of this rule might seem very far-reaching, juries, who judge upon questions of fact, might have neglected less significant contributions of injured parties while, strictly speaking, such a contribution was indeed present. ${ }^{100}$ This was the case in Vanderplank v. Miller (1828), where the jury understood the judge's instruction that the plaintiff's action could only be maintained if there was no want of care on both sides and that the accident was entirely attributable to the fault of the defendants. Although there seems to have been some careless acts on the side of the plaintiff, these were not considered as such, as the jury maintained the action for the plaintiffs. ${ }^{101}$ Thus the all-or-nothing rule might have been applied less harshly than it seems at first sight.

In other cases, the idea of 'ordinary' care seems to act more as a threshold, in the sense that the amount of negligence on the part of the injured party, to deprive him of his action, must be such that he did not exercise ordinary care. If there was some negligence on the part of the injured party, but not to such a degree that it can be said that he did not exercise ordinary care, his claim would be upheld. Examples of cases in which the injured party was excused from his negligence because it was insignificant compared to the improper behaviour of the wrongdoer cannot only be found traffic accidents cases but also in cases concerning trespass, theft, the demolition of a house and accidents between boats navigating on a river. ${ }^{102}$ Thus, the ordinary care doctrine in these cases was dealt with in a way that created some room for judgements in which the injured party was awarded the total amount of damages regardless of the negligence on his part.

In 1838, this interpretation of the ordinary care rule was confirmed by the Court of Exchequer in Bridge v. Grand Junction Railway Company, a case concerning a collision between two trains. In this case, Mr. Justice Parke explicitly acknowledged the idea that the plaintiff could be entitled to recover damages even when he had been negligent. This is only different when the plaintiff could have avoided the consequences of the defendant's

97 Hawkins v. Cooper (1838) 3 Car. \& P. 474.

98 Even if the preponderant blame was of the wrongdoer, see Lord Campbell in Dowell $v$. General Steam Navigation Company (1855) 119 E.R. 454 (459).

99 See Van Dongen (2014a).

100 Koppe (1970) 37.

101 Vanderplank v. Miller (1828) 173 E.R. 1119 (1120).

102 For examples see: Chaplin v. Hawes and Others (1828) 172 E.R. 543, Davies v. Mann (1848) 152 E.R. 588 and Thorogood v. Bryan (1849) 137 E.R. 452, Bird v. Holbrook (1828) 130 E.R. 911, Lynch v. Nurdin (1841) 113 E.R. 1041, Jordin v. Crump (1841) 151 E.R. 1256, Barnes v. Ward (1850) 175 E.R. 277, Walters v. Pfeil (1829) 173 E.R. 1189 and Sills v. Brown (1840) 173 E.R. 452. 
negligence by ordinary care, because in that case he is regarded as the author of his own wrong. ${ }^{103}$ The negligence of the injured party could therefore no longer be used to deny his claim for damages, unless his negligence was the direct cause of the injury. ${ }^{104}$ Later cases in the following years echoed this reasoning, with judges centring their judgment around the question whether the plaintiff had "substantially" or "fairly" contributed to the accident. ${ }^{105}$ In 1840, Mr. Justice Coleridge ruled that what mattered was not whether the injured party had contributed to the extent of the injury or damages, but whether he had (substantially) contributed to the occurrence of the injury in the case Sills v. Brown. ${ }^{106}$ Later cases often referred to this consideration.

The courts no longer seemed to consider just any degree of contributory negligence to be enough to bar someone from claiming damage; the negligence had to be substantial. The role of the injured party's fault in relation to the wrongful behaviour on the part of the defendant in causing the injury was also investigated. The relevance of the way in which the faults on both sides related both to each other and to the accident also appears from the quote of Sir W.H. Maule (1788-1858), a judge of the Court of Common Pleas, that 'there may be a distinction between cases where the act of the defendant is an unlawful act, and those in which the injury arises out of a matter of negligence only'. ${ }^{107}$ Apparently, the seriousness of the fault had become important for the consequences of the contributory negligence of the injured party.

\subsubsection{Davies v. Mann and the last opportunity rule}

As shown in the previous section, the question whether the injured party's conduct was culpable was eclipsed by the inquiry into whose behaviour came last in the early 19th century. Although there were still some cases in which theories of causal computation could be discerned, the focus came to lie on the extent of the culpability on the side of the injured party. The attention given to the timing of the parties' respective negligence in the courts of Kings Bench and Common Pleas would, however, re-emerge after the decision in Davies v. Mann in 1842. ${ }^{108}$ Around the middle of the 19th century, the requirement of a substantial contribution to the accident developed into the 'last opportunity rule', which locates the blame on the party that had the last chance to avoid the accident or injury. This rule frames contributory negligence in terms of causation, like earlier cases in which terms of causation were used, ${ }^{109}$ and centres the judgement around the question whether a causal link can be established between the behaviour of the injured party and the (occurrence of) the accident.

103 Bridge v. Grand Railway Company (1838) 150 E.R. 1134.

104 See Harper \& James (1956) 1243.

105 Phrases like this can be found in Sills v. Brown (1840) 173 E.R. 452; Thorogood v. Bryan (1849) 137 E.R. 452; Senior v. Ward (1859) 1 EL. \& EL. 387; Morgan v. Rarey (1860) 175 E.R. 1062 and also in the commentary of Foster \& Finlason on Springett v. Ball (1865) 4 F. \& F. 471. These cases are discussed more elaborately in Van Dongen (2016) 67.

106 Sills v. Brown (1840) 173 E.R. 452.

107 See Marriot v. Stanley (1840) 133 E.R. 458.

108 See Harper \& James (1956) 1242, who refer amongst others to Vanderplank v. Miller (1828), Luxford v. Large (1833), Pluckwell v. Wilson (1832), Sills v. Brown (1840), Raisin v. Mitchell (1839).

109 The use of causal imputation in early common law was discussed in Section 3.1.2. Examples of $19^{\text {th }}$ century cases in which terms of causation can be found are Flower v. Adam (1810) 127 E.R. 1098 and Deane v. Clayton (1817) 129 E.R. 196. 
The leading direction on the last opportunity rule was given in Davies v. Mann (1842). In this case, someone negligently driving a wagon hit a donkey that had been left behind on the road. At first instance, Mr. Justice Erskine argued that, while it might have been illegal to leave the donkey behind, the owner of the donkey could still maintain an action against the driver if the proximate cause of the injury was attributable to the want of proper conduct on the driver's part. ${ }^{110}$ On appeal, the defendant argued that Mr. Justice Erskine should have adhered to the principle of law that where an accident was the result of faults on both sides, neither party could maintain an action. ${ }^{111}$ The Court of Exchequer, however, reached the same conclusion as Mr. Justice Erskine. According to Mr. Justice (Baron) Parke: 'the mere fact of negligence on the part of the plaintiff in leaving his donkey on the public highway was no answer to the action, unless the donkey's being there was the immediate cause of the injury'. ${ }^{112}$ There is no claim for damages if the immediate cause of the accident lies in the behaviour of the injured party, or, as it is often put, if the injured party's fault has 'directly contributed' to the occurrence of the injury. The key question is thus which party had the last, and therefore the better, opportunity to avoid the damage; that party should then bear the damage. ${ }^{113}$

After the introduction of the last opportunity rule, the legal basis for this rule was questioned. One view based the rule on the intensity of fault or on comparative fault; the fault of the person who had the last opportunity to avoid the damage would be considered more serious than the fault of the other party. ${ }^{114}$ Another view focussed on the causal character between the fault and the damage; the fault of the injured party was not the legal or proximate cause of the damage if the wrongdoer could have avoided the damage i.e., contributory negligence then breaks the link between the fault of the wrongdoer and the damage which occurred. ${ }^{115}$ Quite possibly the only reason for the last opportunity rule was the growing aversion to the contributory negligence rule. ${ }^{116}$ In that sense the case law, based on equity, intended to mitigate the rigidness of the old contributory negligence rule. ${ }^{117}$

\subsubsection{Confirmation of the last opportunity rule}

The ruling in Davies v. Mann set a standard for following cases. ${ }^{118}$ In Tuff v. Warman, a case brought before the Exchequer Chamber in 1858, Mr. Justice Wightman ruled that the proper question to put to the jury in a case concerning contributory negligence should be:

110 Davies v. Mann (1848) 152 E.R. 588.

111 Davies v. Mann (1848) 152 E.R. 588. A similar judgment was delivered a few years earlier, in 1832, in the case of Vennall v. Garner (1832) 149 E.R. 298, a case in which two ships had collided. There it was decided that if an accident was the result of combined negligence, neither can recover against the other.

112 Davies v. Mann (1848) 152 E.R. 588.

113 Jansen (2007) 668.

114 According to MacIntyre (1940) 1225, the underlying reason for the escape from the harshness of the contributory negligence bar in last clear chance cases is that the defendant's negligence was relatively greater than that of the plaintiff.

115 Weyts (2003) 331, with references.

116 See also Williams (1951) 247; Keeton (1984) 464.

117 Williams (1951) 236; Koppe (1970) 42.

118 In Dowell v. General Steam Navigation Company (1855) 119 E.R. 454 (459), for example, Mr. Justice Campbell explicitly referred to Davies v. Mann whilst applying the last opportunity rule. 
'whether the damage was occasioned entirely by the negligence or improper conduct of the defendant, or whether the plaintiff himself so far contributed to the misfortune, that, but for his own negligence or want of ordinary and common care and caution on his part, the misfortune would not have happened. In the first case, the plaintiff would be entitled to recover, in the latter not; as, but for his own fault, the misfortune would not have happened. Mere negligence or want of ordinary care or caution would not, however, disentitle him to recover, unless it were such, that, but for that negligence or want of ordinary care and caution, the misfortune could not have happened; nor, if the defendant might by the exercise of care on his part have avoided the consequences of the neglect or carelessness of the plaintiff.' 119

This question, which is a clear application of the rule in Davies v. Mann, was subsequently referred to as the standard when it comes to contributory negligence. ${ }^{120}$ In 1875, the last opportunity rule even made it to the House of Lords. In Radley v. London and North Western Railway Company, a truck had been left behind by its owners and was subsequently damaged. The House of Lords decided that the accident would not even have happened if the truck had not been left behind but it would not be enough to prevent the injured party from recovering damages. The House acknowledged the general proposition that a plaintiff could not recover if they contributed to the accident but also noted that the last opportunity rule was 'equally well established' and concluded that this rule could thus not be ignored. The original direction to the jury, which claimed that the accident must be caused 'solely by the negligence of the defendant' in order for the plaintiff to recover, was judged to be contrary to the last opportunity rule and wrong in point of law. ${ }^{121}$ The House of Lords thereby confirmed the last opportunity rule and the judgements in Davies v. Mann and Tuff v. Warman on which this rule was based.

\subsection{The extension and the restriction of the last opportunity rule}

In 1916, the Privy Council in the Loach case stretched the last opportunity rule to include cases in which the defendant did not in fact have the last opportunity to avoid the disaster but would have had such an opportunity if he had exercised due care. ${ }^{122}$ The person who would have had the last opportunity to avoid the damage if he had exercised due care (the constructive last opportunity) had to bear the damage ${ }^{123}$ - this preceding negligent act being the decisive cause of the damage. The same reasoning can be found in some cases over the next two decades. ${ }^{124}$ The rule was extended in The Eurymedon (1938) where the Court of Appeal applied the rule from the Loach case to contemporaneous negligence. It was stated that if one of the parties (the plaintiff or the defendant) in a common law action had actually,

119 Tuff v. Warman (1858) 5 C.B. (N.S.) 572.

120 See, e.g., Walton v. The London, Brighton and South Coast Railway Company (1868), H. \& R. 424 and Witherley v. The Regent's Canal Company (1862) 176 E.R. 28.

121 Radley v. London and North Western Railway Company (1875) L.R. 10 Ex. 100. See also Lord Blackburn in Dublin Wicklow \& Wexford Ry. v. Slattery (1878) 3 App. Cas. 1207 (if the injured party by exercising due care could have avoided the consequence of the wrongdoer's negligence he cannot recover).

122 British Columbia Electric Railway v. Loach (1916) 1 AC 719. It has been argued that in this case it superseded the last opportunity rule in favour of the rule of greater fault. See also MacIntyre (1940) 1245 et seq.; Williams (1945) 107.

123 Weyts (2003) 330.

124 See Koppe (1970) 44, with references. 
by observation, been aware of the negligence of the other party and failed to exercise reasonable care towards the negligent injured party, then that party was solely responsible. ${ }^{125}$ In this case neither party had had the last opportunity to avoid the damage, but one would have had this opportunity, because one would have been aware of the danger, if it had not been for his own negligence. ${ }^{126}$

A first restriction of this rule was made by the House of Lords in Volute (1922), which only applies when a clear line between contributing acts can be made. When two acts can be distinguished in time, only the second one is relevant; however, when this is not the case and when the second act stands in such a close relation to the first that it would not have been possible without the preconditions set by that act, the plaintiff can also rely on the first negligent act, so that the contributory negligence doctrine applies here. ${ }^{127}$ A second restriction was applied in Swadling v. Cooper (1930), concerning a collision between a motor car and a motor cycle, where the judge, at first instance, directed the jury that if they found both parties to be substantially to blame for the accident, they should absolve the defendant. According to this judge, the element of who was responsible for the last act of negligence did not necessarily need to play a role. The Court of Appeal set the decision aside because the principles of the last opportunity rule had not been respected. In contrast the House of Lords decided that from the moment the parties became aware of their respective positions, there could have been no time for the defendant to take any action to avoid the impact and therefore the negligence of both parties had contributed to the collision. ${ }^{128}$ The applicability of the last opportunity rule for cases of simultaneous negligence was denied; the jury had to decide which fault preponderantly caused the damage that occurred. ${ }^{129}$

\subsection{Towards partial damages in English common law}

Although the general approach to contributory negligence in relation to the partition of damages as recorded in the Law Reform (Contributory Negligence) Act of 1945 (see below) seems to have been one of 'all or nothing', the law in action might have been different. Juries often allowed recovery in cases of contributory negligence and a compromise in the jury room resulted in some diminution of the damages awarded due to the fault of the injured party (see below). These juries had a good precedent for their rulings: the admiralty courts - which based their decisions on admiralty law, not common law - used the same rule as juries in cases of contributory negligence (weighing the negligence of both parties and striking a balance between them). ${ }^{130}$ Various variants of damage partition can be found. ${ }^{131}$ The simplest possible and the oldest method of apportionment is to divide the damages equally between the negligent parties. This was the method which had been developed, around 1700 , by the English admiralty courts, ${ }^{132}$ which had no jury and were

125 The Eurymedon (1938) 41; Williams (1951) 224.

126 Williams (1951) 225.

127 Admiralty Commissioners v. S.S. Volute (1922) 1 AC 129 (HL); Wester (1976) 101.

128 Swadling v. Cooper (1930) [1931] AC 1.

129 Koppe (1970) 48.

130 Ulman (1933) 33.

131 The idea of the distribution of damages as mentioned in Exodus XXI.35-36 can also be found in Anglo-Saxon England in law 23 of the laws of King Ine. See Thorpe (2004) 51.

132 Beckham v. Chapman (1695) Burrell 270, 167 E.R. 568; Noden v. Ashton (1706) Burell 290, 167 E.R. 577. See McGuffie (1953) 142 et seq. 
strongly influenced by international rules derived from the civil law. ${ }^{133}$ The rules which were applied in the earliest decisions in collision cases were not uniform. ${ }^{134}$ This was settled in 1815 in The Woodrop-Sims when it was decided that a partition in halves was also to be applied when faults were not equally serious, ${ }^{135}$ where a collision is caused by want or due diligence or of skill of both sides, the loss must be apportioned between them. ${ }^{136}$ However this may be, English law continued to adhere to this rule of equal partition ${ }^{137}$ until the enactment of the Maritime Convention Act in 1911, when it conformed with (Article 4 of) the Brussels Maritime Convention of $1910^{138}$ by adopting a statute providing for a division of the damages 'in proportion to the degree in which each vessel was at fault.' ${ }^{139}$

In the common law, the principle of the partition of damages was not officially introduced until the Law Reform (Contributory Negligence) Act of 1945 . $^{140}$ The case of Cayzer, Irvine \& Co. v. Carron Co. (1884) made it clear that the practices of Admiralty law did not extend to common law. In this case, which was brought before the Admiralty division of the House of Lords, Lord Blackburn (1813-1886) declared that the rule of [common, EvD \& HV] law is that if the blame causing the accident lies on both sides, however small that blame may be on one side, the loss lies where it falls', thereby rejecting the application of a partition of damages outside the scope of Admiralty law. ${ }^{141}$ Within the common law, one had still to abide by the traditional 'all or nothing' rule.

However, as already mentioned above, juries might have often disregarded the official rule in favour of the mitigation or partition of damages. Several examples can be found in 19th century case law. In Smith v. Dobson (1841) where, despite the fact that strict instructions were given to the jury as to the effect of contributory negligence (namely, an absolute bar), the jury decided to award one quarter of the damages. The reasoning of the jury based on comparative faults was left unaffected on appeal. ${ }^{142}$ Another example is the case of Raisin v. Mitchell brought before the Court of Common Pleas in 1839. This case concerned an accident between two ships. One of the ships ran into the other ship, causing it to sink. The defence claimed that there were several factors on the side of the injured ship that contributed to the accident. After hearing the case, the jury decided to award only half of the damages claimed. This partial award of damages came as a surprise to both parties as well as to the judge, Lord Chief Justice N.C. Tindal (1776-1846), who had not given any instruction in this direction. When asked for a clarification, the foreman of the jury declared that 'there were faults on both sides'. ${ }^{143}$ Despite the objections of the defendant, Tindal

133 Prosser (1953) 475. See also Turk (1950) 226 et seq.

134 Hillyer (1936) 115.

135 McGuffie (1953) 144.

136 The Woodrop-Sims (1815) 165 E.R. 1422.

137 Hay v. La Neve (1824) 2 Shaw Sc. App. Cas. 395; The Milan (1861) 167 E.R. 167; Cayzer, Irvine \& Co. v. Carron Co. (1884) 9 AC 873.

138 I.e. the International Convention for the Unification of Certain Rules to Govern the Liability of Vessels in Case of Collisions, and a protocol thereto (signed in Brussels on 23 September 1910). For the text see e.g. Knauth (1958) 39 et seq. (see especially Art. 4, on p. 39).

139 See Maritime Conventions Act of 1911, 1 \& 2 George V, c. 57, § 1 (1). This provision provided that if, having regard to all the circumstances of the case, it is not possible to establish different degrees of fault, the liability shall be apportioned equally.

140 See 8 \& 9 Geo. VI, c. 28.

141 Cayzer, Irvine \& Co. v. Carron Co. (1884) 9 AC.

142 Smith v. Dobson (1841) 133 E.R. 1057; MacIntyre (1940) 1229 et seq.

143 Raisin v. Mitchell (1839) 173 E.R. 979. See also MacIntyre (1940) 1229. 
upheld the verdict after the jury confirmed that they had considered the whole matter. Raisin $v$. Mitchell thus offers a practical application of the principle of the partition of damages long before it became an official rule. In their report of the case a few years later, Carrington and Payne noted that the verdict 'seems to be quite correct and sustainable in point of law' and substantiated their judgement with references to earlier cases such as Bridge $v$. Grand Junction Railway Company, Marriot v. Stanley and Sills v. Brown. ${ }^{144}$ Remarkably, Carrington and Payne seem to have considered the decision to award partial damages to be in line with the last opportunity rule, which could also be discerned in other cases around the same period, almost viewing it as a logical conclusion to these developments. ${ }^{145}$

Signs of a discussion about the consequences of the all-or-nothing rule can also be found in two cases from 1850, Greenland v. Chaplin and Rigby v. Hewitt. In both cases the jury had awarded, contrary to their instruction by the judge, full damages to the injured party, despite evidence of (some) contributory negligence on his side. ${ }^{146}$ When the cases were brought before Mr. Justice C.E. Pollock on appeal, he repealed the jury decisions, but did express his doubts as to whether the consequences of the current doctrine would be appropriate in all cases. In Greenland v. Chaplin Pollock admitted that he was not sure whether it would be reasonable to hold a person responsible for 'all the consequences which may under any circumstances arise, and in respect of mischief which could by no possibility have been foreseen, and which no reasonable person would have anticipated' ${ }^{147}$ In Rigby v. Hewitt, Pollock similarly remarked that he had some doubts as to the extent of the damages which were recoverable. ${ }^{148} \mathrm{He}$ acknowledged that a person should be responsible for all foreseeable consequences, but seemed to have had some doubts concerning the coverage of consequences that no one could have foreseen. In both cases, however, the emphasis of Pollock's comments seems to lie on the causal link to the damage, which should not be too remote from the accident itself, and less on the rules regarding contributory negligence. Moreover, Pollock was very careful to point out that these doubts did not apply to the cases at hand and he went to great lengths to clarify that he did not want to question earlier precedents or to go against the doctrine as a whole. ${ }^{149}$

The case of Springett v. Ball, which occurred about ten years later, in 1865, is even more interesting in the context of contributory negligence. In this case, the jury came to a verdict similar to the one in Raisin v. Mitchell. ${ }^{150}$ Although the judge's direction to the jury in this case was along the same lines as the last opportunity rule, the jury seemed to have considered the outcome of that rule to be unsatisfactory and they awarded mitigated damages instead. Although the jury did not explicitly state their reason for doing this, Chief Justice Sir Alexander J.E. Cockburn (1802-1880) noted that 'it is evidently the result of a compromise'. From his conclusion that the jury obviously evaded 'the difficulty and responsibility of a decision', which was 'most unsatisfactory', it is clear the Chief Justice was not very pleased with the verdict. The commentary accompanying the report of this case in Foster \& Finlason's law reports is not very positive either. The commentary argues

144 Commentary of Carrington \& Payne on Raisin v Mitchell (1839) Car. \& P. 613.

145 Commentary of Carrington \& Payne on Raisin v Mitchell (1839) Car. \& P. 613.

146 Commentary of Carrington \& Payne on Raisin v Mitchell (1839) Car. \& P. 613. See also

Foster \& Finlason's commentary on Springett v. Ball (1865) 4 F. \& F. 471.

147 Greenland v. Chaplin (1850) 155 E.R. 104

148 Rigby v. Hewitt (1850) 155 E.R. 104.

149 Greenland v. Chaplin (1850) 155 E.R. 104

150 Springett v. Ball (1865), 4 F. \& F. 471. 
that the incident either occurs or does not and thus there is no question of any degree when considering who caused it thereby giving a clear insight into the arguments against the partition of damages. ${ }^{151}$

All in all, it is interesting to note that all three juries in Smith v. Dobson, Raisin v. Mitchell and Springett v. Ball quite independently of each other decided to mitigate the awarded damages. Apparently there was a shared sense in these cases that the all-or-nothing approach when awarding damages was unfair in the given circumstances. Not everyone shared this outlook. Although the jury's verdict in Raisin v. Mitchell was considered to be in line with earlier case law (by Carrington and Payne), a similar verdict in Springett v. Ball was met with harsh criticism. Likewise, in the Exchequer Chamber Mr. Justice Pollock expressed some doubts on the matter in both Greenland v. Chaplin and Rigby v. Hewitt, he was very careful not to go too far in his suggestions and also made sure to show his deference to the contemporary regime of awarding either all, or none of the damages. Thus, it is not surprising that it would still take several decades until these ideas made it into legislative drafting i.e., in 1945. Meanwhile, the broadening of the last opportunity rule had paved the way for a less stringent understanding of contributory negligence.

The principle that an injured party who was partly responsible for his own harm could not recover damages in tort would remain the official doctrine until the Law Reform (Contributory Negligence) Act of 1945. Section 1 (1) of this at provided the rule that in such cases the claim does not fail but the defence of contributory negligence may apply and if it applies it may lead to a reduction of the amount of damages to be paid. This reduction is based on the respective degrees of the responsibility of the parties. The question to be answered is not only to what extent the behaviour involved was likely to cause the event, but above all what is needed is a balancing of the respective faults by the judge. ${ }^{152}$ Ultimately decisive is what the court/judge considers to be 'just and equitable'. ${ }^{153}$ With the Act, the contributory negligence rule, with its all-or-nothing approach, and the last opportunity rule became inoperative. ${ }^{154}$

\section{CONCLUDING REMARKS}

In order to rethink the differences and similarities between the common and civil law tradition as to the issue of the role and consequences of the contributory conduct of the injured party that contributed to his own loss in the law of delicts, this article has described the development of the solutions and consequences provided in civil law and (English) common law. The solutions found in common law are not as different from the ones in civil law; even before a concept of contributory negligence existed there might have been remarkable similarities in the way one solved this issue. Interestingly, in both (medieval) canon law as in various early modern cases in common law (and even some in civil law) the contributory conduct was considered from a viewpoint of causation: the wrongdoer's act had to be the proximate cause of the damage. Nevertheless, the gradual acceptance of the concept of negligence - which was already present early in the civil law tradition due to the influence of Roman law thereon - can be seen in common law in the early modern period

151 Commentary on Springett v. Ball (1865) in 4 F. \& F. 471.

152 Looschelders (1999) 95. See Denning L.J. in Davies v. Swan Motor Co. Ltd. [1949] 2 K.B. 291 (326).

153 See also Honoré (1983) 123 et seq.

154 See Looschelders (1999) 96, with further references. 
too, and in some cases the negligence of the injured party was already considered. In both legal traditions the result of 'contributory negligence' was one of 'all or nothing'. Moreover, in both traditions, the way in which cases involving contributory negligence were dealt with slowly developed from a very strict rule, depriving the injured party of its action even in the presence of the slightest degree of negligence on their side, into a more lenient approach, in which attempts aimed at doing justice to the relation in which both parties contributed to the accident were made during the $19^{\text {th }}$ century. The English introduction of the last opportunity rule resembles the developments on the continent to a certain degree, because it shifts the focus increasingly to the seriousness of the faults rather than looking solely at the occurrence of the negligence, although the rule places the emphasis more on the timing of the negligence. Thoughts on a partition of damages, which was first applied in civil law jurisdictions in the second half of the $19^{\text {th }}$ century, can be discerned in some $19^{\text {th }}$ century cases in English common law too, as the discussion of the remarks of Justice Pollock have illustrated. Moreover, juries would regularly have mitigated the damages they awarded, rather than applying the all-or-nothing rule. The idea of a partition of damages thus seems to have emerged in English common law around the same time as the introduction of the principle in civil law. Finally, common law introduced the possibility of a reduction, based on the respective degrees of responsibility of the parties in 1945, just as civil law jurisdictions did in the $19^{\text {th }}$ and 20 th century. Thus, there are some clear similarities in the development of the concept of 'contributory negligence' in both the civil law tradition and the common law tradition - indicating that these two legal families might not be as far detached from each other - in the periods studied - as is often believed.

\section{LITERATURE}

Aumann, P., Das mitwirkende Verschulden in der neueren juristischen Dogmengeschichte, diss. Hamburg (1964).

Beale, H.G., 'Causation and Contributory Negligence' in HG Beale (ed), Chitty on Contracts, I (32 ${ }^{\text {nd }}$ edn, Sweet \& Maxwell 2015) 1838-49.

Bohlen, F.H., 'Voluntary Assumption of Risk' (1906-7) 20 Harv. L. Rev. 14-34.

Bohlen, F.H., 'Contributory Negligence' (1907-8) 21 Harv. L. Rev. 233-60.

Buckland, W.W. and McNair, A.D., Roman Law and Common Law. A Comparison in Outline, revised by Lawson, F.H. (2 ${ }^{\text {nd }}$ edn, Cambridge University Press 1974).

Buckland, W.W., A Text-Book of Roman Law from Augustus to Justinian, revised by Stein, P. (3 ${ }^{\text {rd }}$ edn, Cambridge University Press 2007).

Coing, H., Europäisches Privatrecht, I. Älteres gemeines Recht (1500 bis 1800) (C.H. Beck 1985).

Descamps, O., Les origins de la responsabilité pour faute personelle dans le Code Civil de 1840, (LGDJ 2005).

Dondorp, J.H., Schuld en boete. Enige grepen uit de geschiedenis van de onrechtmatige daad, m.m.v. Hallebeek, J. (VU University Press 1998).

Dongen, E.G.D. van, 'Alfenus D.9.2.52.1 geanalyseerd vanuit het perspectief van de retorica' in D Heirbaut, X Rousseaux and A Wijffels (eds), Histoire du droit et de la justice (Presses Universitaires de Louvain 2010) 163-76.

Dongen, E.G.D. van, 'Gesetzgebung, verfahrensrechtliche Realität und Rechtslehre im römischholländischen Recht des 16. bis 18. Jahrhunderts: das Problem des Mitverschuldens bei Schiffskollisionen' (2013) 2 BRGÖ 601-10.

Dongen, E.G.D. van, Contributory Negligence. A Historical and Comparative Study (Brill 2014a).

Dongen, E.G.D. van, 'Hollandsche IJzeren Spoorwegmaatschappij/Morré. Enige rechtsvergelijkende en rechtshistorische beschouwingen over de gevolgen van eigen schuld van de gelaedeerde voor de aansprakelijkheid voor onrechtmatig handelen' (2014b) 1 Pro Memorie 76-101.

Dongen, E.G.D. van and Verdam, H.P., 'The Development of the Concept of Contributory Negligence in English Common Law' (2016) 12 Utrecht Law Review 61-74. 
Gordley, J., Foundations of Private Law. Property, Tort, Contract, Unjust Enrichment (Oxford University Press 2006).

Hallebeek, J., 'Negligence in Medieval Roman Law' in EJH Schrage (ed), Negligence. The Comparative Legal History of the Law of Torts (Duncker \& Humblot 2001) 73-100.

Harper, F.V. and James, F., The Law of Torts, vol 2 (Little Brown 1956).

Heuston, R.F.V. and Buckley, R.A., Salmond and Heuston on the Law of Torts (Sweet \& Maxwell 1996).

Hillyer, H., 'Comparative Negligence in Louisiana' (1936) 11 Tul. L. Rev. 112-26.

Holdsworth, W., A History of English Law, vol 3/8 (Methuen 1966a).

Honoré, A.M., 'Causation and Remoteness of Damage' in A Tunc (ed), Encyclopedia of Comparative Law. Volume XI. Torts. Part I (Mohr Siebeck 1983) 3-156.

Ibbetson, D.J., A Historical Introduction to the Law of Obligations (Oxford University Press 1999).

Jansen, N., 'Duties and Rights in Negligence: A Comparative and Historical Perspective on the European Law of Extracontractual Liability' (2004) 3 Oxford Journal of Legal Studies 443-69.

Jansen, N., '§ 254, Mitverantwortlichkeit des Geschädigten' in R Zimmermann (ed), Historischkritischer Kommentar zum BGB, Bd. 2 Schuldrecht Allgemeiner Teil, 1. Teilband: vor $\$ 241-\$ 304$ (Mohr Siebeck 2007) 655-714.

Kaser, M., Das römische Privatrecht, vol 1 (2 $2^{\text {nd }}$ edn, C.H. Beck 1971).

Kaufmann, H., Rezeption und Usus Modernus der actio legis Aquiliae (Böhlau Verlag 1958).

Keeton, W.P. et al., Prosser and Keeton on the Law of Torts (West 1984).

Knauth, A.W., Knauth's Benedict on Admiralty, vol 6 (M. Bender 1958).

Koppe, P.J.R., Das mitwirkende Verschulden des Verletzten (contributory negligence) im englischen und irischen Schadensersatzrecht (Diss. Kiel 1970).

Kuttner, S., Kanonistische Schuldlehre von Gratian bis auf die Dekretalen Gregors IX: systematisch auf Grund der handschriftlichen Quellen dargestellt (Bibliotheca Apostolica Vaticana 1935).

Landon, P.A., Pollock's Law of Torts (Stevens 1951).

Lange, H., Schadensersatz und Privatstrafe in der mittelalterlichen Rechtstheorie (= Forschungen zur neueren Privatrechtsgeschichte, Band 2) (Böhlau 1955).

Law Commission, Contributory Negligence as a Defence in Contract [Law Commission no. 219] (1993).

Leesen, T., Gaius meets Cicero: Law and Rhetoric in the School Controversies (Wolf Legal Publishers 2009).

Lenel, O., Palingenesia iuris civilis, vol 2 (Bernard Tauchnitz 1889).

Looschelders, D., Die Mitverantwortlichkeit des Geschädigten im Privatrecht (Mohr Siebeck 1999).

Lübtow, U. von, Untersuchungen zur lex Aquilia de damno iniuria dato (Duncker \& Humblot 1971).

Luig, K., 'Überwiegendes Mitverschulden' in Ius Commune, Veröffentlichungen des Max-PlanckInstituts für Europäische Rechtsgeschichte, vol 2 (Klostermann 1969) 187-238.

MacIntyre, M.M., 'The Rationale of Last Clear Chance' (1940) 53 Harv. L. Rev. 1225-52.

Mazeaud, L. et al., Traité théorique et pratique de la responsabilité civile délictuelle et contractuelle, II, (6 $6^{\text {th }}$ edn, Montchrestien 1970).

McGuffie, K.C., Marsden on the Law of Collisions at Sea (Stevens \& Sons 1953).

Medicus, D., Id quod interest. Studien zum römischen Recht des Schadensersatzes (Böhlau 1962).

Mehren, A.T. von and Gordley, J., The Civil Law System (2 ${ }^{\text {nd }}$ edn, Little Brown 1977).

Parisi, F., Liability for Negligence and Judicial Discretion $\left(2^{\text {nd }}\right.$ edn, University of California Press 1992).

Pernice, A., Zur Lehre von den Sachbeschädigungen nach römischem Rechte (Böhlau 1867).

Pollock, F. and Maitland, F.W., The History of English Law before the Time of Edward I, vol 2 (Cambridge University Press 1923).

Prosser, W.L., 'Comparative Negligence' (1953) 41/1 Cal. L. Rev. 1-37.

Re, E.D., 'The Roman Contribution to the Common Law' (1961) 29 Fordham L. Rev. 447-94.

Schoepff, W.A., Selectae decisiones et resolutiones Tubingenses I (J. Georg \& C.G. Cotta 1726).

Schofield, W., 'Davies v. Mann: Theory of Contributory Negligence' (1889-90) 3 Harv. L. Rev. 26377.

Swisher, P.N., 'Virginia should abolish the Archaic Tort Defense of Contributory Negligence and adopt a Comparative Negligence Defence in its Place' (2011) 46 U. Rich. L. Review 359-71. 
Thorne, S.E., Bracton on the Laws and Customs of England (The Belknap Press of Harvard University Press 1968).

Thorpe, B., Ancient Laws and Institutes of England, vol 1 (1840, repr. The Lawbook Exchange 2004).

Tourneau, P. le, Droit de la responsabilité et des contrats (Dalloz 2004).

Turk, E.A., 'Comparative Negligence on the March' (1950) 28 Chi.-Kent. L. Rev. 189-245.

Ulman, J.N., A Judge takes the Stand (Alfred A. Knopf 1933).

Valditara, G., 'Damnum iniuria datum' in A Bascardi et al., Derecho romano de obligaciones: homenaje al profesor José Luis Murga Gener (Centro de Estudios Ramón Areces 1994) 825-85.

Watson, A., The Law of Obligations in the Later Roman Republic (Scientia Verlag 1984).

Wester, K., Mitverschulden im deutschen, englischen und amerikanischen Zivilrecht, diss. Cologne (Schadel \& Wehle 1976).

Weyts, B., De fout van het slachtoffer in het buitencontractueel aansprakelijkheidsrecht (Intersentia 2003).

Wharton, F., A Treatise on the Law of Negligence (Kay and Brother 1974)

Williams, G., 'The Law Reform (Contributory Negligence) Act, 1945' (1945) 9 Mod. L. Rev. $105-36$.

Williams, G.L., Joint Torts and Contributory Negligence (Stevens 1951).

Wollschläger, C., 'Das eigene Verschulden des Verletzten im römischen Recht' (1976) ZRG RA 115-38.

Zimmermann, R., 'Usus modernus legis Aquiliae and Delictual Liability Today' (1990) 1 Stellenbosch Law Review 67-93.

Zimmermann, R., The Law of Obligations. Roman Foundations of the Civilian Tradition (Oxford University Press 1996).

Zimmermann, R., 'Limitation of Liability for Damages in European Contract Law' (2014) 18/2 Edinburgh Law Review 193-224.

\section{LINKS}

1. Coppens, E.C., Animal est substantia, available at $<$ www.medcanonlaw.nl/Animal_est_substantia $>$ accessed 15 July 2016. 